\title{
CAVE BREAKDOWN BY VADOSE WEATHERING
}

\author{
R.A.L. Osborne
}

\begin{abstract}
Vadose weathering is a significant mechanism for initiating breakdown in caves. Vadose weathering of ore bodies, mineral veins, palaeokarst deposits, non-carbonate keystones and impure, altered or fractured bedrock, which is intersected by caves, will frequently result in breakdown. Breakdown is an active, ongoing process. Breakdown occurs throughout the vadose zone, and is not restricted to large diameter passages, or to cave ceilings. The surfaces of disarticulated blocks are commonly coated, rather than having fresh broken faces, and blocks continue to disintegrate after separating from the bedrock. Not only gypsum, but also hydromagnesite and aragonite are responsible for crystal wedging. It is impossible to study or identify potential breakdown foci by surface surveys alone, in-cave observation and mapping are essential.
\end{abstract}

\section{Introduction}

Breakdown is a significant process in both karst and non-karst caves, and it can have implications for the stability of both cave voids themselves and for structures founded on rocks above caves. A range of professionals, including engineering geologists, mining engineers, geotechnical engineers and structural engineers, may be asked to advise on issues relating to cave breakdown, including foundation conditions on cavernous karst, collapse structures in the karst surface and the safety and stability of show caves. Frequently an outside-in approach is taken to the processes of breakdown and collapse and to ways of ameliorating their effects on humans and their technology.

When viewing karst from the inside-out, breakdown is found to be a common and largely natural process within caves. In many cases breakdown has no surface expression or effect. Frequently ground failure and subsidence in karst is not caused by breakdown and the resultant failure of massive bedrock, but the failure of unconsolidated material filling dolines and cave entrances, due to the removal of fines by infiltrating water.

Increasingly, caves are being seen as inherently stable features with life spans, as open voids, extending over hundreds of millions of years, not ephemeral underground landscapes that rapidly disintegrate.

Studies by specialists with experience in working inside karst and an understand- 
ing of how breakdown processes work within karst are essential, both to provide background information and for solving site-specific problems.

\subsection{Breakdown}

Breakdown has been variously defined as a process, as a material, or as both. Davies (1951) defined breakdown as a process:

\section{The failure en masse of the roof or walls of caverns,}

whereas White and White (2000) proposed a narrower definition, which restricted breakdown to the materials:

disarticulated fragments of bedrock that have broken free and fallen into a cave passage.

A broader definition is used here sees breakdown as both the process by which the materials surrounding cave voids become disarticulated and the materials (fragments, blocks) that have become disarticulated.

Whether breakdown (sometimes called collapse) is a cave forming (speleogenetic) or cave destroying process is a matter of contention. Waltham (1974) stated that:

Collapse is frequently cited as the cause of large cave chambers. This is incorrect - in fact the real cause is quite the contrary,... collapse does not form caves, it fills them in.

Most commentators, however (e.g. Bögli, 1980), recognised, and recent discoveries in Mallorca (Gines, 2000) have indicated that breakdown is involved in the development of many large chambers.

Where cave breakdown intersects the ground surface the result is a collapse doline. There is an extensive literature on the origin of collapse dolines, ănd'Susstersic (2000) provides a good review. It is not intended to discuss the interaction between cave breakdown and surface failure here, but rather to concentrate on what observations in caves indicate about the behaviour of breakdown as both a process and a material.

\subsection{Mechanisms causing breakdown}

Davies (1951) applied beam failure models derived from mining engineering to the problem of cave breakdown.

In their classic work on cave breakdown, White and White (1969) identified eight processes activating cavern breakdown:

1- loss of buoyant support by draining of galleries;

2- undercutting of banks by floodwater stoping at the base level;

3- removal of support by free surface stream action;

4- crystal wedging and attack by sulfate mineralization;

5 - frost wedging;

6- undercutting by later cavern development;

7- undercutting and removal of material by vertical shafts and shaft drains;

8 - weakening of ceiling beds through attack by acid surface water. 
All but three (\# 4, 5 and 8 ) of these mechanisms involve the removal of some type of support.

Recently, Slovenian workers have made significant contributions to the study of breakdown. Stanka Šebela and Jose Čar ( ̌̌ebela and Čar, 1991; Šebela, 1996, 1998, Šebela and Čar, 2000) have shown the importance of geological structures such as faults, fault zones and fold axes in the development of breakdown chambers and related collapse dolines at Postojna Cave. Mihevc (1995) recognised that large chambers in vertical caves can form by the breakdown of the rock mass (walls) between two adjacent shafts. Šušteršič (1998, Fig.3B), in describing the development of an unroofed cave, indicated that breakdown is a near-surface weathering phenomenon.

The sediment-filled channel is intersected by the surface weathering zone. Breakdown of the channel ceiling takes place and the fill supports large blocks of the parent rock.

Whereas Davies (1951) dismissed the contribution of earthquakes to cave breakdown, recent work in Croatia (Buzjak, 2000) has emphasised the role of neotectonics in the final failure of cave voids, leading to the development of collapse dolines.

\subsection{Implications of failure mechanisms involving removal of support}

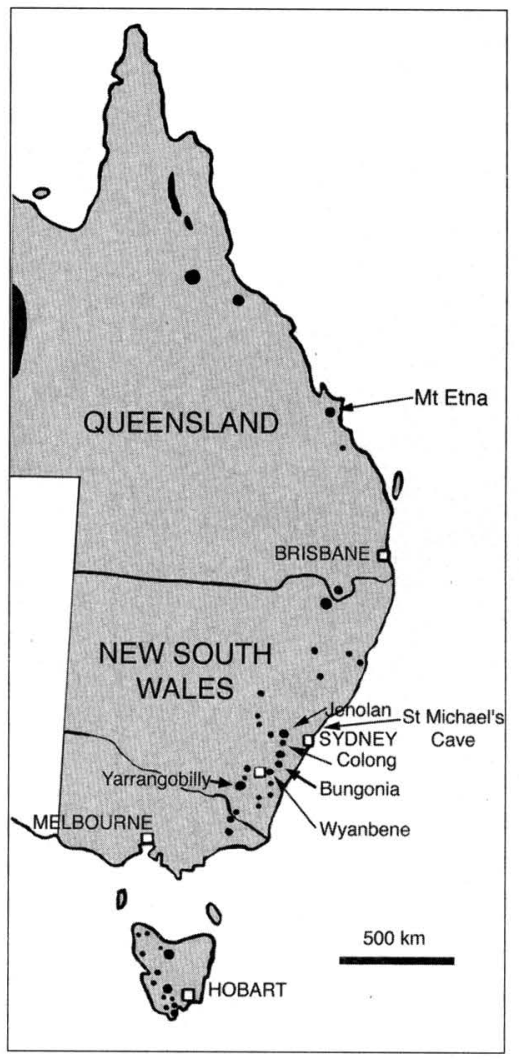

Breakdown in caves is commonly attributed to loss of buoyant support, as phreatic caves are initially drained - the first of the mechanisms proposed by White and White (1969). If breakdown is primarily a product of failure brought about by removal of support, one might expect that:

- Active breakdown would be a common feature of the lower vadose zone (where hydrostatic support has been most recently lost) and a rare feature of the upper vadose zone where a significant time interval has followed loss of hydrostatic support.

- Breakdown would be very common in large passages and quite rare in passages of relatively small dimensions.

- Breakdown should be essentially a process affecting the ceiling and upper walls of cave passages; lower wall and floor breakdown would be unexpected.

- The surfaces of recently fallen blocks should be fresh, as they result from recent

Fig. 1 - Eastern Australia showing locations of sites described. Black dots and zones represent major cavernous karsts developed in Palaeozoic limestones. Based on map by K. Grimes (2000). 
cracks in fresh rock, initiated after the removal of hydrostatic or other support.

- Breakdown should quickly become self-limiting as an arch of equilibrium dimensions is produced.

- Observations in caves in the Palaeozoic limestones of eastern Australia (Fig.1) during the last twenty years and more recently in Europe (Fig.2) have shown that these five expectations are commonly not met. The observations do suggest that vadose weathering of:

- Ore bodies and mineral veins,

- Palaeokarst deposits,

- Non-carbonate keystones,

- Impure, altered or fractured bedrock

is a significant mechanism for triggering breakdown.

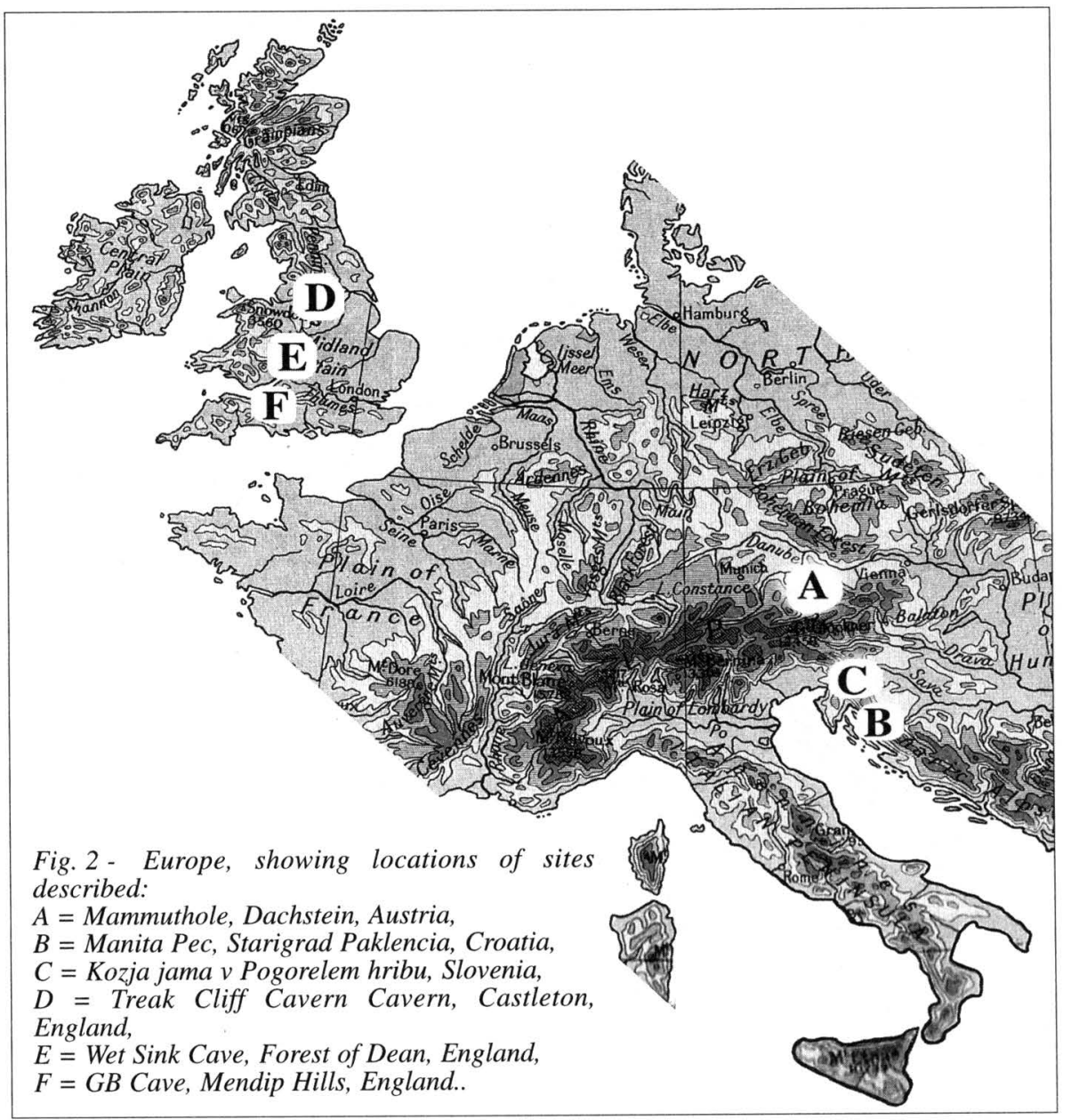




\section{General observations of breakdown in caves}

Whereas there is no doubt that removal of support plays an important role in breakdown, the author's observations indicate that vadose weathering plays a significant role in many, if not most, occurrences of breakdown in high strength (strongly indurated) limestones. Breakdown in poorly indurated limestones, such as aeolian calcarenites, has not been investigated.

The following general observations have been made of breakdown in caves.

\subsection{Breakdown is an active, ongoing process}

The most striking impression gained from examining active breakdown sites in caves is that zones in the rock are literally (and rapidly) in the process of "blowing apart" or disintegrating.

Since the environment in caves tends to protect breakdown features from the elements, the apparent "freshness" and "rapidity" of the process is more often than not an illusion. What is clear, however, is that breakdown is a process active today, not one that occurred mostly in the past (i.e. just after the caves entered the vadose zone).

\subsection{The position of breakdown relative to the water table}

In all of the areas where observations have been made, breakdown, particularly that resulting in the development of large breakdown chambers, was commonly found to be occurring high in the vadose zone. That is, in areas quite removed from where the limestone has recently lost hydraulic support from phreatic water.

High-level breakdown chambers are quite common. European examples include Grosse Dom in Mammuthole, Austria (Fig.2A) and Manita Pec in Croatia (Fig.2B). A good example is Kozja jama v Pogorelem hribu, (Fig.2C) in the high karst of Slovenia near Mt Nanos. It is an isolated breakdown chamber (Fig.3) in which breakdown processes are currently active. The entrance elevation of Kozja jama $\mathrm{v}$ Pogorelem hribu is $1090 \mathrm{~m}$, some $1,000 \mathrm{~m}$ above the regional karst water table.

\subsection{Breakdown in small-section passages and chambers}

Whereas breakdown does play a major role in the development of some large chambers, breakdown is by no means restricted to large-section cave passages. In the limestone caves examined by the author this is only a qualitative observation. However, Klimchouk and Andrejchuk (this volume) have shown quantitatively that, in large gypsum caves, there is no direct correlation between large passage diameter and the occurrence of breakdown.

\subsection{Breakdown occurs in cave walls and floors}

Davies (1949) noted that collapse of cave walls accounts for a large amount of rock debris in caves. The author's observation have shown that breakdown is not restricted to the cave ceiling and the area just below the ceiling-wall junction, as might be expected from failure due to loss of support, but also occurs at a variety of levels in cave walls and at the wall-floor junction.

In Treak Cliff Cavern, Castleton, England (Fig.2D), heaving of bedrock can be observed at the wall-floor junction. At Jenolan Caves, N.S.W. Australia (Fig.1), gyp- 


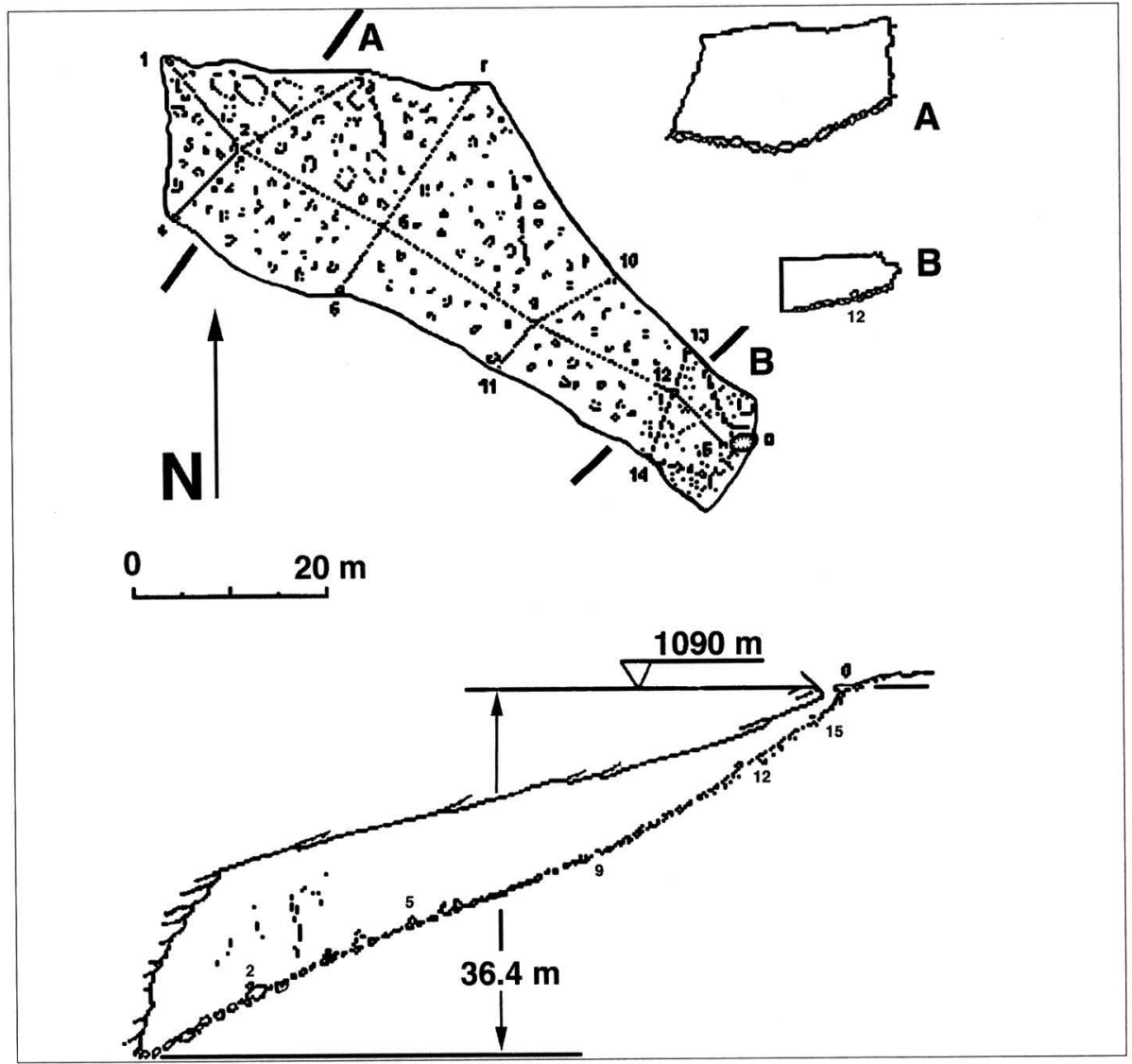

Fig. 3 - Kozja jama v Pogorelem hribu, Note proximity of breakdown chamber to plateau surface. Map and sections from survey by D. Rojsec and F. Šušteršič, September 5, 1997.

sum wedging is resulting in active failure by exfoliation of thin scales of limestone around the walls and ceiling surfaces of a circular-section passage with a diameter of about $1.5 \mathrm{~m}$.

\subsection{Surfaces of breakdown blocks}

Fallen breakdown blocks, in general, do not have the clean, fresh bedrock surfaces that might be expected if they were the result of failure along recently propagated cracks. On the contrary, recently fallen blocks are commonly coated with thin layers of clay, limonite and other minerals, giving them a weathered appearance. On being broken open, however, the centres of such blocks are found to be composed of fresh, unaltered limestone.

The walls of the Grand Dome, Glory Hole Cave, Yarrangobilly Caves, N.S.W. Australia (Fig.1), have a distinct yellow colour, as do fallen blocks from the break- 
down pile lying on the chamber floor. The interior of these blocks, however, is dense (sound) white limestone, transected by sparry veins containing small crystals of pyrite (Osborne, 1996). In this, and many other instances, breakdown blocks are found to bounded by pre-existing discontinuities in the limestone (veins, joints, micro-faults etc.) that have been opened/mobilised by weathering, rather than by recent fractures of sound rock.

\subsection{Continued fragmentation of fallen blocks}

At many of the localities examined (e.g. Kozja jama v Pogorelem hribu), fallen blocks in breakdown piles were found to be in the process of disintegration. This disintegration was clearly taking place after the rocks had fallen (Fig.4). This continuation of fragmentation, principally due to crystal wedging, plays an important role in the removal of breakdown material from cave voids.

Post-parting disintegration, dissolution of breakdown by strong acid released from the weathering of pyrite, and dissolution of breakdown piles below the water table provides the answer to Waltham's dilemma (see above). Whereas breakdown may in some cases fill caves, commonly the breakdown pile is removed, resulting in continued expansion of the cave void.

\subsection{Movement of breakdown piles may be independent of fresh breakdown}

Breakdown piles in caves, like talus slopes and cones in the surface environment, may move without any new material being added to them. Also, like their surface equivalents, breakdown piles should be considered to be in a constant state of slow motion. As a consequence, movement of a breakdown pile may considerably alter the

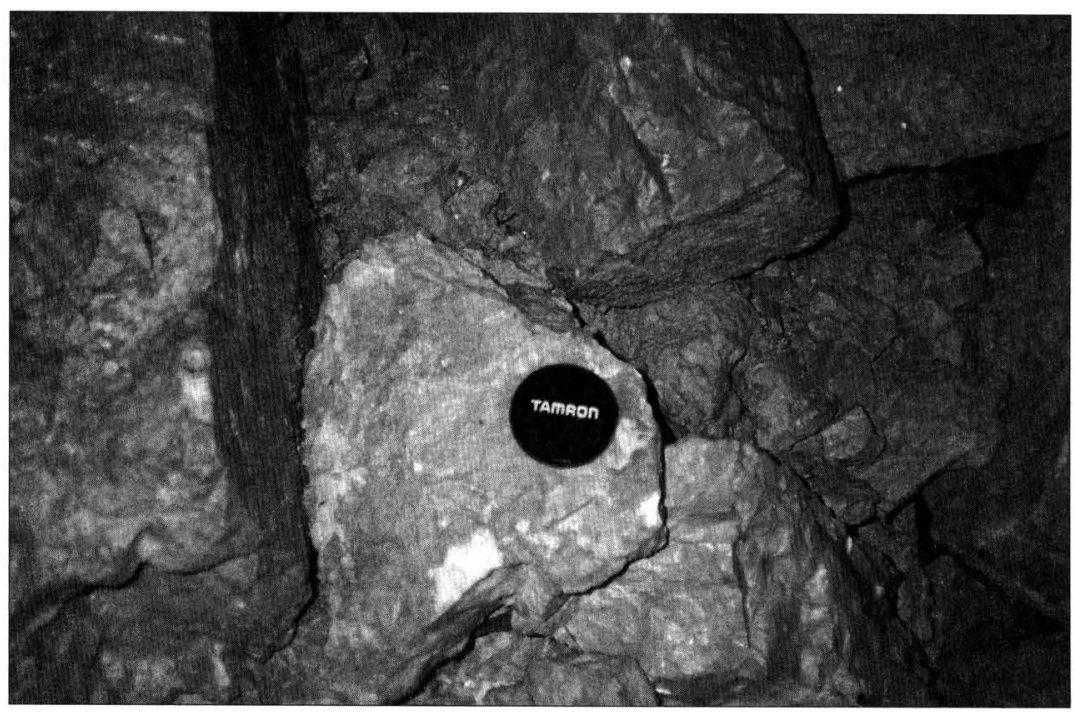

Fig. 4 - Limestone blocks in breakdown pile, Kozja jama v Pogorelem hribu. Note "weathered" surface of blocks. Blocks show continuing post-fall disintegration. Lens cap $55 \mathrm{~mm}$. 
internal geography of a cave, without any change occurring in the shape or stability of the enclosing bedrock void.

When movement of breakdown blocks in caves is investigated it is essential to establish if there is significant new breakdown of the cave wall or ceiling, or if the movement is restricted to the pile (or sections of the pile) itself.

\subsection{Minerals involved in crystal wedging}

Whereas gypsum, generally derived from the weathering of pyrite, is the most commonly observed mineral involved in crystal wedging, it is not the only species involved. Hydromagnesite has been implicated in breakdown at Wet Sink Cave, Forest of Dean, England (Fig. 2E) and at Jenolan Caves. Secondary aragonite, in the form of spheres, $25 \mathrm{~mm}$ in diameter, composed of acicular crystals, is actively wedging rock apart at Jenolan Caves. Ferroan dolomite appears to be the precursor of hydromagnesite at Wet Sink Cave and Jenolan Caves and of aragonite at Jenolan Caves.

\section{Breakdown initiated by vadose weathering}

In the vadose zone, karst materials are exposed to air, undersaturated/oxygenated water and variations in humidity and temperature. Whereas the response of highpurity limestone and gypsum to these conditions will largely be to dissolve, or gain mass through precipitation, other materials (e.g. sulfides, clays, ferromagnesian minerals, etc) will respond by weathering, much as they do elsewhere close to the Earth's surface.

It is the vadose weathering of Earth materials, other than high-purity bedrock, in the karst rock mass that can be a significant trigger for breakdown.

\subsection{Breakdown by weathering of mineralised bodies and veins}

A range of ore bodies including Mississippi Valley Type deposits, fluorite and low temperature iron carbonates can be emplaced in limestones. These may be intersected by caves, or may be weathered-out to form caves. Osborne (1993a, 1996, 2000) described how weathering of palaeokarst ore bodies, and veins emplaced in the surrounding bedrock by them, resulted in breakdown.

Though generally stable in the phreatic zone, ore bodies containing sulfides will weather rapidly in vadose conditions, and may be easily removed from the rock mass. In the Underground River at Jenolan Caves large blocks of weathered iron carbonate ore (not bedrock) have fallen from the ceiling, exhuming a previously-filled cavity in the limestone (Osborne, 1993a). The original ore contained calcite, ferroan dolomite and pyrite.

As the ore body is removed, sulfide-bearing veins, extending into the rock mass, will also weather, resulting in the development of breakdown chambers. This process, based on observations at Wyanbene Cave, N.S.W. Australia (Fig.1) is illustrated in Fig. 5. 


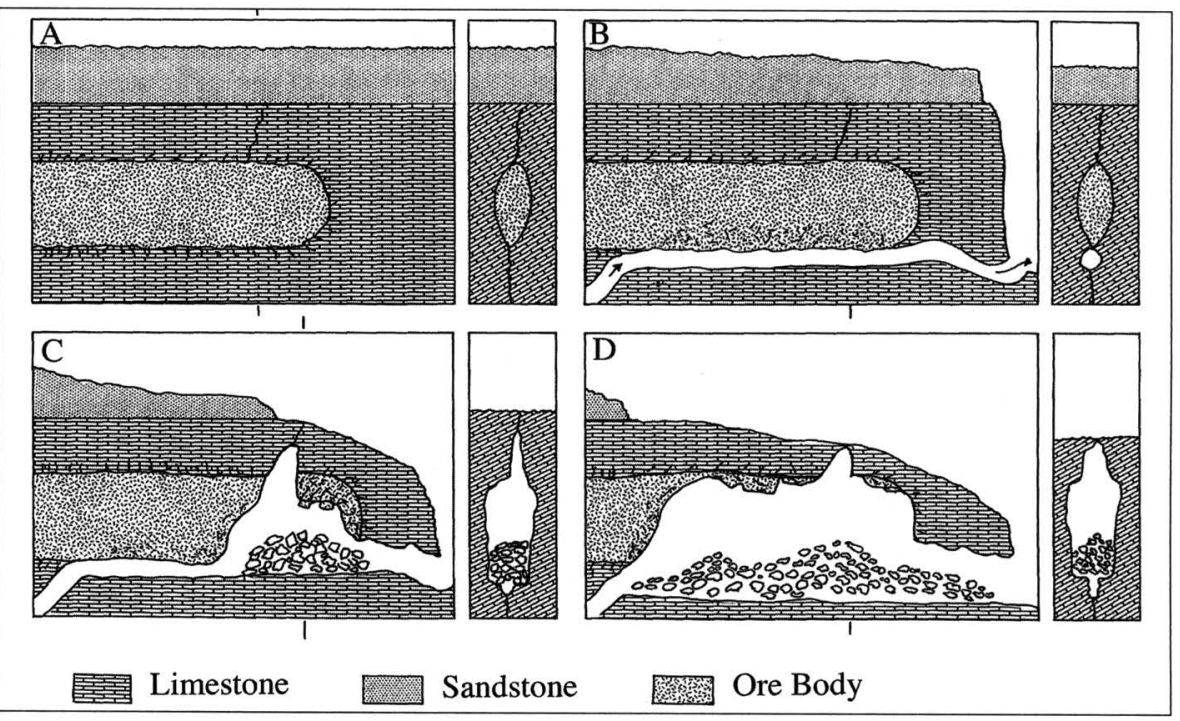

Fig. 5 - Vadose excavation of a palaeokarst-hosted ore body, resulting in chamber and aven formation. Diagram after Osborne (1996) based on observations in Wyanbene Cave, N.S.W., Australia: A = Mineralised palaeokarst deposit / palaeokarst-hosted ore body in limestone below unconformity; $B=$ Ore body acts as aquiclude. Rising phreatic water forms pressure tube below ore body. Surface erosion lowers base level and exposes ore body to vadose conditions, body begins to weather; $C=$ Sedimentary cover begins to retreat. Further weathering of the ore body forms a chamber. Vadose water entering via the exposed joint oxidises sulfides resulting in the aven forming by vadose dissolution. Weak and dissolved material is removed by modern (underfit) stream; $D=$ Out-of-scale chamber forms. Sulfides in small veins oxidise to form gypsum, which causes breakdown of limestone adjacent to ore body. Palaeokarst remnants form substrate for aragonite and gypsum speleothems. Note major upstream development of chamber is delineated by end of covering sediment, which inhibits entry of oxygen-rich vadose water into limestone.

In Wet Sink Cave, active breakdown is occurring at specific sites in the Chunnel, an elongate cave passage with a rectangular profile and a breakdown floor, developed along a joint in sub-horizontally-bedded Carboniferous limestone containing iron mineralization (Lowe, 1993). The Chunnel is currently the highest level passage known in Wet Sink Cave, located some $30 \mathrm{~m}$ above the present stream bed. Breakdown is not found in the lower-level stream passages. At active breakdown sites the bedrock is intersected by veins of carbonate iron ore, which are weathering. Breakdown was occurring by the dislodgement of vein-bound blocks from the cave ceiling, partly as a result of crystal wedging by hydromagnesite.

\subsection{Breakdown by weathering of palaeokarst deposits}

Palaeokarst deposits in limestone (Osborne, 2000) and gypsum (Klimchouk and Andrejchuk, this volume) can be significant foci for breakdown. Palaeokarst deposits are commonly lithologically and chemically different from the bedrock in which they are housed. They are generally scattered (apparently irregularly) through the rock mass.

Palaeokarst bodies may not be exposed at the surface. The position of exposed 
palaeokarst bodies at the surface gives little indication of their likely disposition within the rock mass as a whole.

This situation is well illustrated at Jenolan Caves. Jenolan Caves are developed in a narrow body of steeply dipping, massive Silurian limestone. Bodies of horizontally bedded, laminated palaeokarst limestone (Caymanite) (Osborne, 1993a, 1999) occur throughout the rock mass. Pyrite is a common, but not particularly abundant, mineral in the palaeokarst deposits.

Breakdown associated with weathering of palaeokarst occurs in The Grand Archway at Jenolan Caves (Figs 6 and 7). Whereas most of the ceiling of the
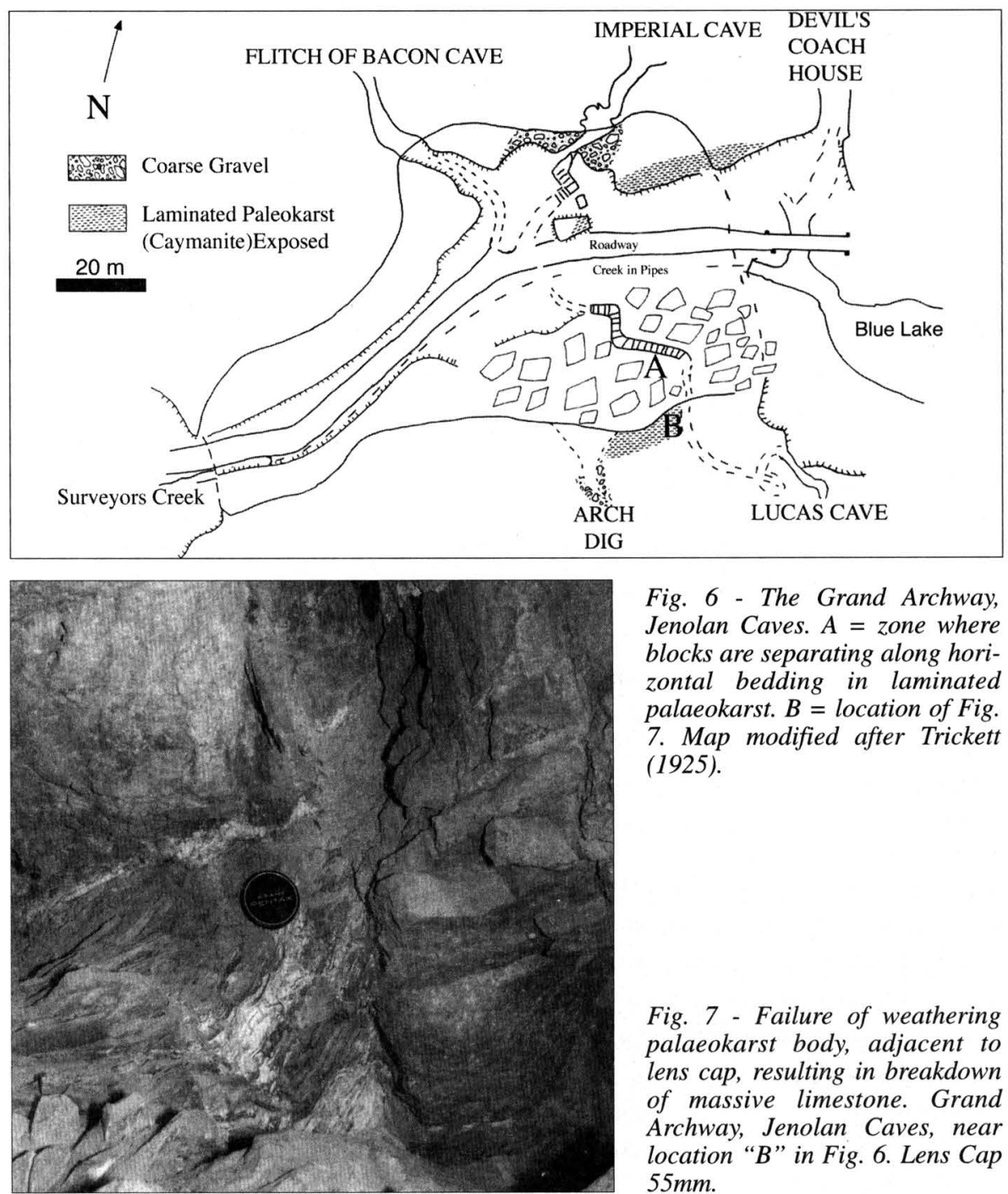

Fig. 6 - The Grand Archway, Jenolan Caves. $A=$ zone where blocks are separating along horizontal bedding in laminated palaeokarst. $B=$ location of Fig. 7. Map modified after Trickett (1925).

Fig. 7 - Failure of weathering palaeokarst body, adjacent to lens cap, resulting in breakdown of massive limestone. Grand Archway, Jenolan Caves, near location " $B$ " in Fig. 6. Lens Cap $55 \mathrm{~mm}$. 
Archway is composed of massive, steeply dipping limestone, palaeokarst bodies are exposed in the ceiling adjacent to the southern wall. Here a combination of gypsum wedging due to weathering of pyrite and lack of support is resulting in slab failure of palaeokarst from the cave ceiling along horizontal bedding. This process also brings down adjacent, and/or interspersed, blocks of massive limestone.

It is important to note that a geological survey of the limestone outcrop on the surface above the Grand Archway would give no indication of the presence, or disposition, of the palaeokarst bodies.

\subsection{Breakdown by weathering of keystones}

Breakdown may be triggered by the weathering of intrusive rock bodies, such as dykes, which have come to act as keystones for cave ceilings.

Non-karst caves, such as some sea caves, frequently develop by the weathering and erosion of dykes in more resistant rocks, and then expand by undermining and breakdown of the surrounding rock and the removal of breakdown debris. Breakdown is triggered by weathering and progressive failure of the dyke, which acts as a central keystone for the cave ceiling.

This process can be seen in St Michael's Cave, a sandstone sea cave at Newport, N.S.W. Australia (Fig.1). The cave is an elongate chamber developed along a pyroclastic dyke that intrudes a sequence of sandstones and mudstones. The dyke now forms the keystone for the cave ceiling (Osborne and Branagan, 1992).

A significant breakdown event in 1980 raised concern about stability of the cave itself, and of houses constructed above it. The event appears to have been triggered by heavy rain and sullage seeping down the dyke, leading to its failure close to the cave ceiling (Fig.8). As a consequence, a significant quantity of sandstone and mudstone slabs detached from the cave ceiling along bedding planes (Fig.9).

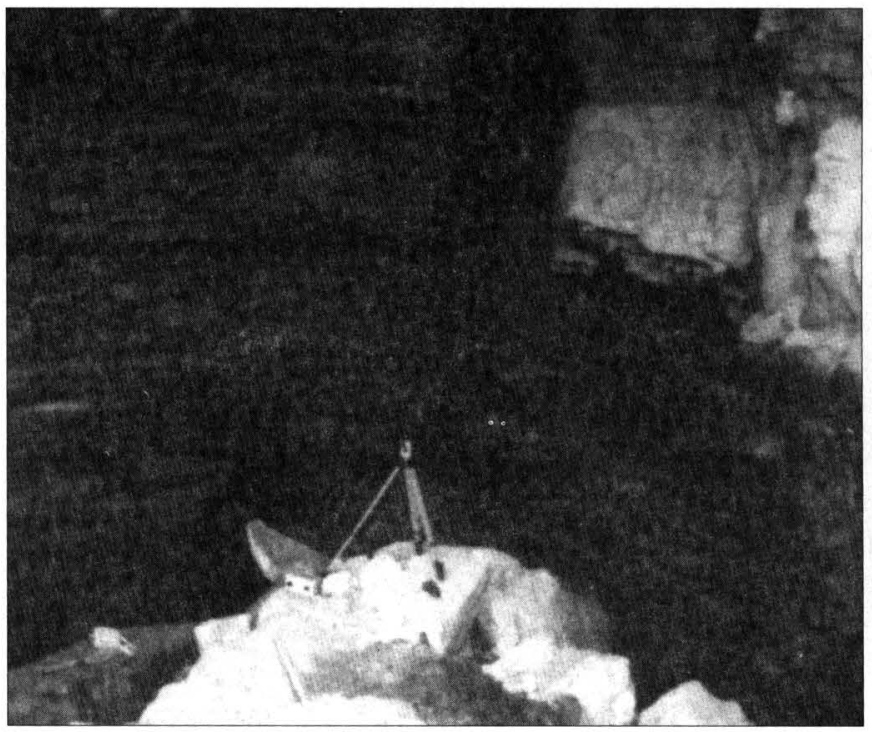

Fig. 8 - St Michael's

Cave, looking west. The dyke is the vertical dark band in the background just right of centre. The tripod is on top of a fresh breakdown cone produced by major ceiling failure along the dyke in 1980. Blocks in the pile are sandstone, the clastic dyke material weathers to form black silty sand. Note failure along horizontal bedding planes in the upper right of the image. 


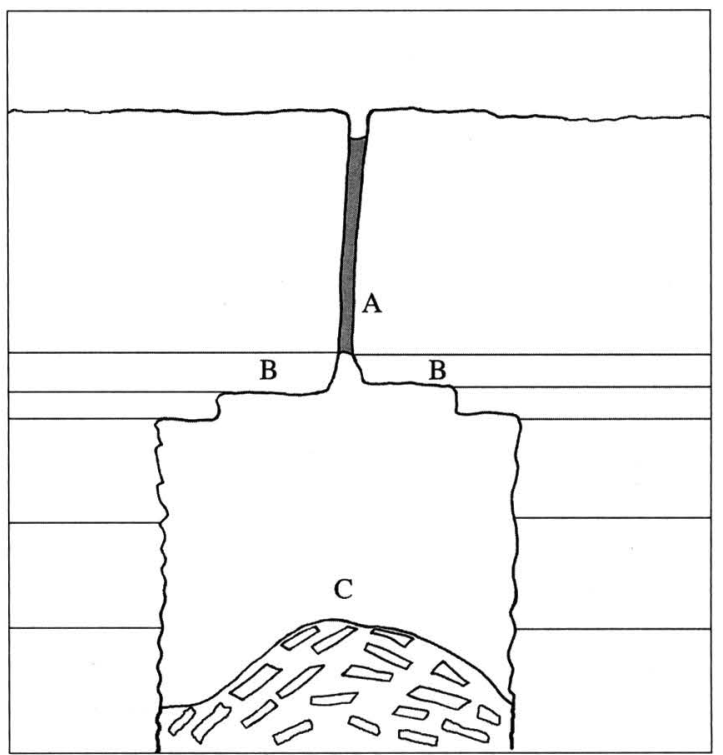

Fig. 9 - Diagrammatic cross-section looking west, showing breakdown where dyke forms a keystone in the centre of the ceiling, St Michael's Cave, Newport, north of Sydney. $A=$ clastic dyke, $B=$ sandstone beds, $C=$ breakdown cone

In karst caves, dykes, and/or vertical sills, intersected by the margins of dissolution cavities can also act as keystones, and their progressive failure may lead to breakdown. Woof's Cavern in Lannigan's Cave, Colong Caves, N.S.W. Australia (Fig.1) is a large chamber developed in vertically-bedded limestone with a vertical sill forming its eastern wall (Osborne, 1985). Breakdown along the eastern side of the chamber occurs when failure of the sill as a keystone results in detachment of slabs from the ceiling along horizontal joints (Fig. 10).

Since weathering of intrusive rock bodies can be a significant trigger for cave breakdown, it is important to know where such bodies intersect karst rocks and the relationship between the intrusive bodies and the cave void.

In-cave surveys are required to determine the relationship between intrusions and caves. This is because the absence of dykes on the karst surface does not indicate their absence in the rock mass, even at quite shallow depths. For example, Osborne (1993b) described three dykes exposed at shallow depth $(<10 \mathrm{~m}$ below the surface) in caves at Bungonia Caves, N.S.W. Australia (Fig.1). One dyke is exposed in a cave passage within $1 \mathrm{~m}$ of the surface. However, at the surface directly above it, no trace of the dyke, only massive limestone, is exposed.

\subsection{Breakdown by weathering of impure/altered bedrock}

Karst features are most commonly encountered and best expressed in soluble rock of high purity - that is, in limestones, dolostones, gypsum and salt containing more than $95 \%$ soluble mineral. Caves can, however, develop in rocks that are considerable less pure, and some cave forming processes (e.g. thermal and hydrothermal speleogenesis) may alter the composition of the wall rock in the cave.

As a consequence, caves may penetrate rocks that undergo a range of vadose 


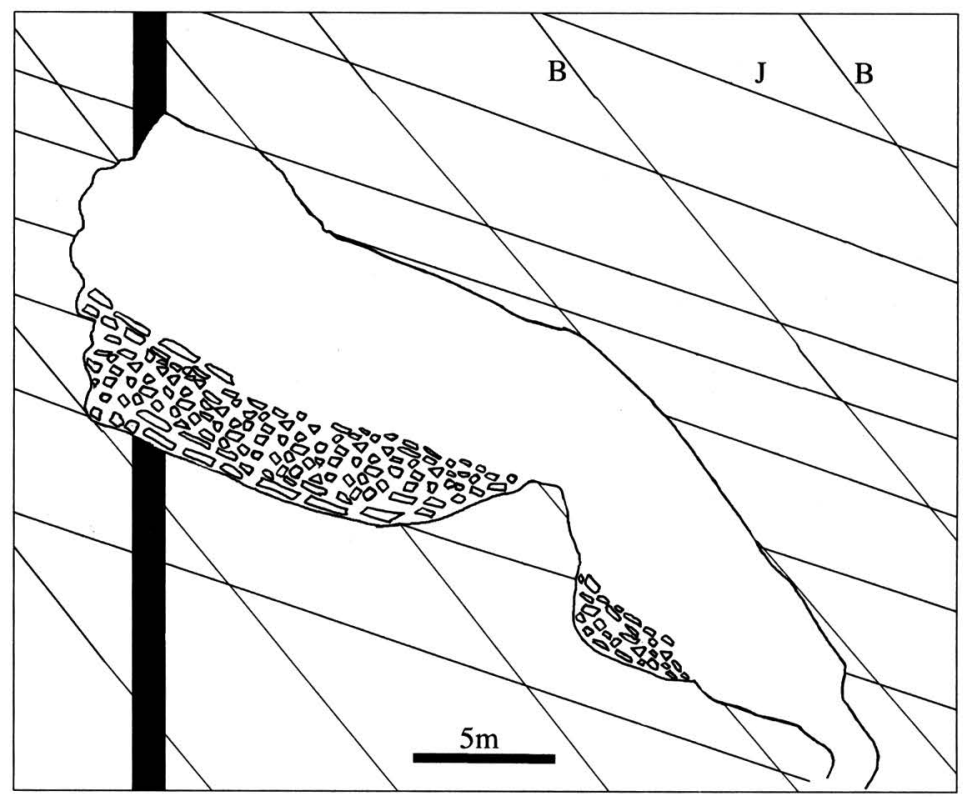

Fig. 10 - Diagrammatic cross-section looking south, showing breakdown where dyke occurs at the side of cavity, based on Woof's Chamber, Lannigan's Cave, Colong Caves. $B=$ widely spaced steeply dipping beds. $J=$ gently dipping beds. Section after survey by Pryke and $T$. Moulds, Sydney University Speleological Society, 2002.

weathering processes, not just dissolution. These can result in fragmentation of the rock and, hence, breakdown.

In 1986 a major sinkhole failure occurred in the Snowy Mountains Highway at Yarrangobilly, New South Wales, Australia (Osborne, 1996). This failure was due largely to removal of poorly consolidated sediments filling a natural solution cavity in the limestone. Internal examination revealed that the rock of the cavity wall was composed of weatherred, altered limestone, not pure massive limestone like the majority of the Silurian limestone at Yarrangobilly. These cavity walls were fairly weak and beginning to fail as the supporting sediments were removed.

GB Cave, Mendip Hills, England (Fig.2F) one of the largest caves developed in the Mendip Hills of south-western England, consists of a small-section passage that connects to a series of large, breakdown-modified chambers. The small-section passage is developed in thin beds of relatively pure limestone, interbedded with more shaley units. In present vadose conditions the shaley units are breaking down and failing, due to oxidation of iron-bearing phases and hydration of clays, whereas the limestone units (which were more soluble under phreatic conditions) now form resistant beds (Fig.11).

\subsection{Breakdown by weathering of fractured bedrock}

Šebela $(1996,1998)$ has demonstrated that a strong relationship exists between breakdown chambers and crush zones related to faults. As well as weakening the fab- 


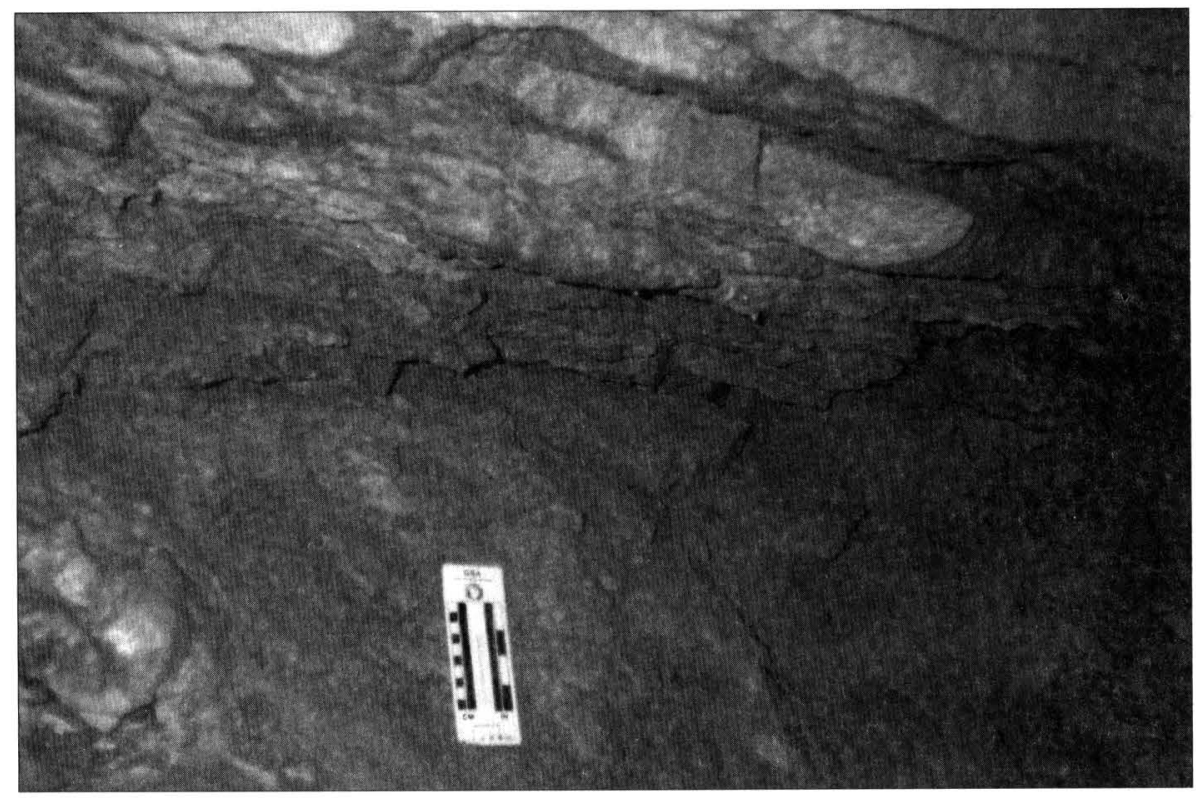

Fig. 11 - Weathering bedrock in cave wall, GB Cave, Mendip Hills, England. Note that dark, impure shaley beds are failing, whereas purer limestone (pale) is more resistant under vadose conditions

ric of the rock these zones provide easy access for percolation water, and thus both vadose dissolution and precipitation. Whereas vadose dissolution will open spaces between angular clasts in crush zones, and thus promote breakdown, vadose precipitation will cement them together and inhibit breakdown. In studying potential breakdown sites it is not enough simply to know that there are crush zones through which water is infiltrating. It is essential to establish if the water is opening the zones by dissolution, or sealing them by precipitation.

Zupan-Hajna (1997) showed that, in addition to bedrock fragments, crush zones contain fines infiltrating slowly from the surface, loam deposited into fracture zones during floods and tectonic clay produced by pressure solution of the limestone along the faults. While they remain in-situ, these materials may help to stabilise the fractured rock, particularly if they are cemented. Their removal, however, will tend to activate breakdown.

\section{Some practical implications}

\subsection{The need for in-cave investigation}

Many of the materials whose weathering is the focus for breakdown will not be recognised by geological or geotechnical surveys of the limestone surface. This is particularly the case with dykes, sills and palaeokarst bodies. Surface investigations, 
and conventional approaches such as drilling and geophysical techniques (which are notoriously unreliable in cavernous karst), will not enable either the mechanism driving breakdown or its likely outcome to be determined.

Subsurface investigations by specialists familiar with the cave environment are essential when breakdown is being investigated, or if it is suspected as being a geotechnically significant process.

\subsection{Most cave breakdown has no immediate surface effect}

Active breakdown zones and inactive breakdown piles are common features of limestone caves, but few are related directly to failure and subsidence of the land surface, and most do not represent a threat to the integrity of natural cave cavities.

It is commonly difficult for those whose principal experience is in dealing with artificial cavities, such as mines and tunnels, to appreciate how stable natural cavities (lacking props, beams and rock bolts) actually are.

\subsection{Caves are difficult to destroy}

Whereas caves are highly vulnerable environments and their contents are very easily damaged, physically destroying caves (i.e. causing the cave void to fail) is quite another matter. Attempts by limestone miners to destroy caves in limestone quarries in eastern Australia (e.g. at Mt Etna, Queensland, Fig.1) proved to be quite unsuccessful (Osborne, 1994). Similarly fragile mineral deposits are frequently discovered in relatively intact conditions in caves intersected by quarries (see, for example, Leel-Ossy and Vigassy, 2001).

It would appear that the only reliable way to destroy cave voids is to emulate natural processes and remove the enclosing rock from around them. The final natural failure of cave voids, producing "unroofed caves" (Mihevc et al, 1998) may well be due more to surface lowering removing the roof from above the cave (see Kortnik and Šušteršič, 2000, and Kortnik in this volume), than to breakdown stoping removing the ceiling from below.

\subsection{Breakdown processes are promoted by infiltrating water}

The weathering processes that can trigger breakdown are promoted by contact between metastable Earth materials and fresh oxygenated water. Water acts to lubricate discontinuities between disarticulating blocks, promoting their separation from the rock mass. Infiltrating water will also wash out clay and crushed fines from between blocks in fracture zones. With breakdown, as with many other karst processes, avoiding the concentration of surface drainage is an important management consideration.

\subsection{Weathering of pyrite is a powerful agent for promoting breakdown and stoping}

Weathering of pyrite has a two-fold effect on carbonate rocks, firstly it releases strong acid to dissolve them and secondly, where the reaction products are not quickly washed away, it results in the growth of gypsum crystals, which wedge the rock apart. It is crucial that beds and rock masses (e.g. palaeokarst deposits) that contain weathering pyrite are identified in any investigation of breakdown. 


\subsection{Surface failure may result from more than one process}

Whereas surface failure in karst is usually the result of unconsolidated materials failing, more than one process (see above and Klimchouk and Andrejchuk in this volume) may be contributing to the outcome. This is another reason why it is essential to investigate karst sites from both inside and out, rather than basing solutions on information derived from the surface and on literature-derived knowledge of internal processes.

\section{REFERENCES}

BÖGLI A. 1980. Karst Hydrology and Physical Speleology. Springer-Verlag, Berlin.

BUZJAK N. 2000. Collapse structures as a connection between the karst surface and under ground (examples from Croatia). Acta Carsologica 29 (2): 65-81.

DAVIES W.E. 1949. Features of cave breakdown. National Speleological Society Bulletin 11: 34-35 \&72.

DAVIES W.E. 1951. Mechanics of cave breakdown. National Speleological Society Bulletin 13: 36-43.

GINES A. 2000. Patterns of collapse chambers in the endokarst of Mallorca (Balearic Islands, Spain). Acta Carsologica 29 (2): 139-148.

KLIMCHOUK A. and ANDREJCHUK V. (This volume). Karst breakdown mechanisms from observations in the gypsum caves of the Western Ukraine: implications for subsi dence hazard assessment.

KORTNIK J. and ŠUŠTERŠIČ F. 2000. Modelling the stability of a very large cave room; Case study: Brezno pri Medvedovi konti. Acta Carsologica 29 (2): 149-160.

LOWE D.J. 1993. The Forest of Dean caves and karst: Inception horizons and iron-ore deposits. Cave Science 20 (2): 31-43.

LEEL-OSSY S. and VIGASSY T. 2001. The new crystal caves at Beremend and Nagyharsany. Proceedings of the $13^{\text {th }}$ International Congress of Speleology, Brasilia.

MIHEVC A. 1995. The morphology of shafts on the Trnovski gozod plateau in west Slovenia. Cave and Karst Science 21 (2): 67-69.

MIHEVC A., SLABE T. and ŠEBELA S. 1998. Denuded caves: An inherited element in the karst morphology; the case from Kras. Acta Carsologica 27 (1): 165-174.

OSBORNE R.A.L. 1985. Letter, Dykes and cave development at Colong Caves, New South Wales. Helictite 23 (1): 33-35.

OSBORNE R.A.L. 1993a. Geological Note: Cave formation by exhumation of Palaeozoic palaeokarst deposits at Jenolan Caves, New South Wales. Australian Journal of Earth Sciences 40: 591-593.

OSBORNE R.A.L. 1993b. A new history of cave development at Bungonia, N.S.W. Australian Geographer 24 (1), 62-74.

OSBORNE R.A.L. 1994. Caves, cement, bats and tourists: karst science and limestone resource management in Australia. Journal and Proceedings of the Royal Society of New South Wales 127: 1-22.

OSBORNE R.A.L. 1996. Vadose weathering of sulfides and limestone cave development-evi dence from eastern Australia. Helictite 34 (1): 5-15.

OSBORNE R.A.L. 2000. Paleokarst and its significance for speleogenesis. 113-123. In: KLIMCHOUK A., FORD D., PALMER A. and DREYBRODT W. (Eds.) Speleogenesis: Evolution of karst aquifers. Huntsville: Natl. Speleol. Soc. 
OSBORNE R.A.L. and BRANAGAN D.F. 1992. Pseudokarst in the Sydney Region. 26th Newcastle Symposium on Advances in the Study of the Sydney Basin, University of Newcastle, Department of Geology Publication, no. XXX: 95-102.

ŠEBELA S. 1996. The dolines above the collapse chambers of Postojnska Jama. Acta Carsologica 25: 241-250.

ŠEBELA S. 1998. Collapse chambers in Postojnska Jama and the relation to geological struc ture. Kras i speleologica 9 (XV11): 161-168.

ŠEBELA S. and ČAR J. 2000, Velika Jersanova Doline- a former collapse doline. Acta Carsologica 29 (2): 201-212.

ŠUŠTERŠIČ F. 1998. Interaction between a cave system and the lowering karst surface case study: Laski Ravnik. Acta Carsologica 27 (2): 115-138.

ŠUŠTERŠIČ F. 2000. Are collapse dolines formed only by collapse? Acta Carsologica 29 (2): 213-230.

WALTHAM A.C. 1974. Caves. London: Macmillan.

WHITE E.L. and WHITE W.B. 1969. Processes of cavern breakdown. National Speleological Society Bulletin 13 (4): 83-96.

WHITE E.L. and WHITE W.B. 2000, Breakdown morphology. 427-429. In: KLIMCHOUK A., FORD D., PALMER A. and DREYBRODT W. (Eds.) -Speleogenesis: Evolution of karst aquifers. Huntsville: Natl. Speleol. Soc.

ZUPAN-HAJNA N. 1997. Mineral composition of clastic material in fault zones and open fis sure in karst rocks, examples from SW Slovenia. Proceedings of the $12^{\text {th }}$ International Congress of Speleology, La Chaux-de-Fonds. vol. 1: 33-36. 